\title{
AN ATTEMPT TO ESTIMATE FOOD BIOMASS ELIMINATED ANNUALLY \\ BY THE COD (GADUS MORHUA L.) POPULATION IN THE BALTIC, BASED ON STUDIES IN 1977-1982
}

\author{
PRÓBA OSZACOWANIA MASY POKARMU ELIMINOWANEGO \\ W CIĄGU ROKU PRZEZ POPULACJĘ DORSZA (GADUS MORHUA L.) \\ W BALTYKU, NA PODSTAWIE BADAŃ PROWADZONYCH W LATACH 1977-1982
}

\author{
Institute of Ichthyology, \\ Szczecin
}

\begin{abstract}
Daily coefficients obtained from long-term studies on stomach content of cod feeding within subareas 25 and 26 are compared with ICES data on the biomass of the stock inhabiting subareas 25-32. The total biomass of food consumed annually by the stock is, calculated as well as the biomass of food (and its components) eaten by cod in various age classes. The values are calculated separately for each year within 1977-1982, 6-yr means being given as well.
\end{abstract}

\section{INTRODUCTION}

Apart from herring and sprat, cod is the third dominant species in the Baltic fish fauna in terms of biomass and abundance. The species is thus one of major consumers using this sea's natural resources. As opposed to the two plankton-feeding species mentioned, the cod feeds mostly on benthos and other fish. Populations of other species using food similar to that of cod are negligible compared to the size of the Baltic cod population. Thus the latter can be considered a natural agent of biological elimination of the two above-mentioned elements of fish communities. By determining the intensity of the elimination, an insight into at least two problems could be gained. On the one hand, a basis on which to estimate productivity of certain benthos components (and also 
macroplankton) whose biomass is not known in detail, would be formed; and on the other hand, the pression of cod on commercially important herring and sprat populations could be evaluated. There are data demonstrating the pression, as one of the major factors in the two species natural mortality, to affect the standing stock of the two species and, in consequence, their catches (Elwert owski, 1982).

The present work is an attempt to assess the total annual consumption and the amount of food consumed by cod of various age groups. The assessment is based on data on mean daily rations and stock biomass. The data on food composition and amount were obtained from an area much smaller than that inhabited by the population as a whole. Although this could affect the precision of the estimates, the data given here, those on the total consumption in particular, allow to realise the order of magnitude of quantitative relastionships involved in effects of cod, as a consumer, on certain components of the Baltic communities.

\section{MATERIALS AND METHODS}

Materials from two sources are used in this work. The basic materials consist of data on daily rations of cod in various age classes, the data being obtained during studies in subareas 25 and 26 in 1977-1982 (Załachowski, 1985). These data were refered to the biomass of cod inhabiting subareas 25-32. The data on cod population biomass were taken from ICES materials (Anon., 1983), with the kind permission of the ICES General Secretary. The mean annual biomass in each calendar year was calculated (similarly to the procedures used by the ICES Working Group; Anon., 1982) by multiplying the biomass at the beginning of the year by an "average" operator

$$
1-\mathrm{e}^{-\mathrm{Z}}
$$

$\mathrm{Z}$

To calculate the total mortality coefficient, "Z" values describing the fishing mortality, „F" in various age groups (Anon.. 1983) were used, assuming the natural mortality, "M" equal to 0.3 . Differences between the mean biomass and that at the beginning of a year are illustrated in Fig. 1 plotted from average values for the whole period of study.

\section{RESULTS}

Total food biomass

Fig. 2 shows the cod population biomasses in various calendar years and corresponding food weights. A rather wide range (more than 200 thou. $t$ ) of biomass values over the period of study makes it possible to follow a relationship between the two parameters under comparison. A relatively lou correlation coefficient $(0.76)$, obtained with a linear 


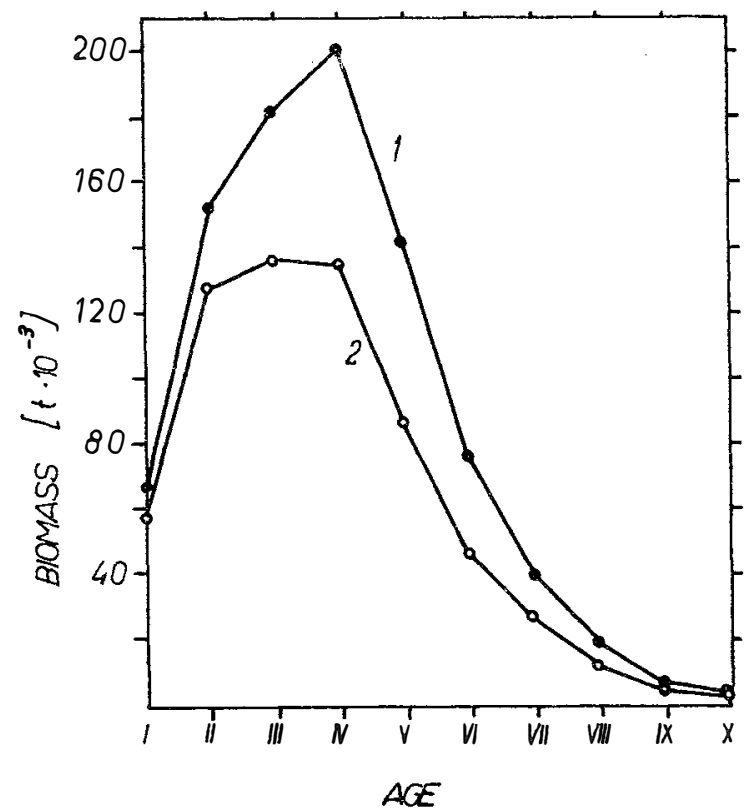

Fig. 1. Mean cod biomass for the period $1977-1982(1=$ at the beginning of the year; $2=$ mean during the year; $t=$ metric tonnes)

relationship assumed, indicates a rather poor fit of that type of a relationship. This could be explained assuming considerable and stock density-independent differences

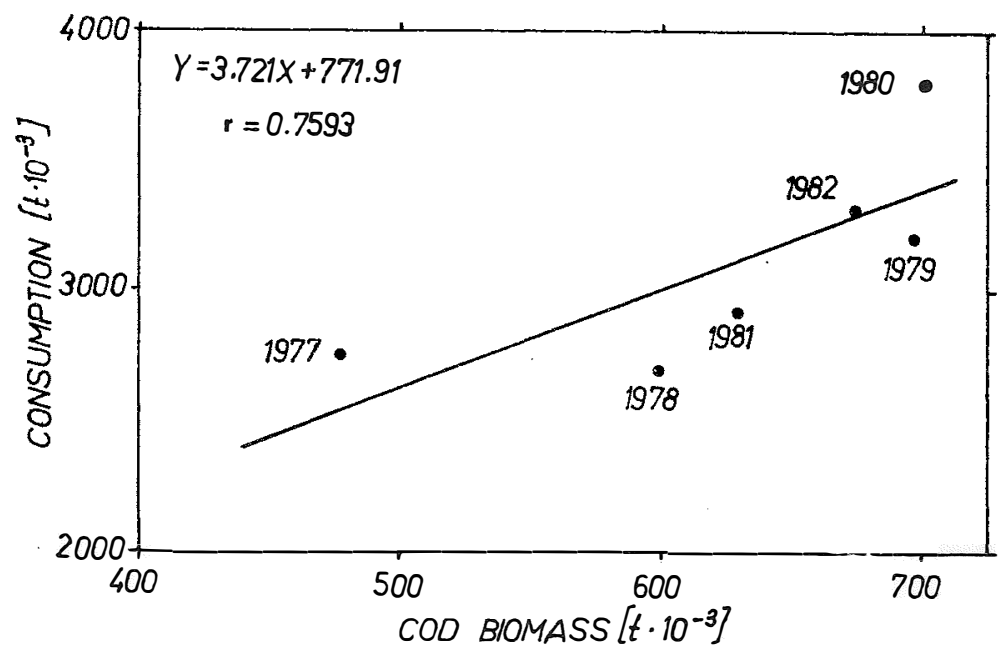

Fig. 2. Relationship between total annual consumption (Y) and cod population biomass (X) in various calendar years $(r=$ correlation coefficient; $t=$ metric tonnes $)$ 
between cod feeding intensity in various years. However, as the detailed study on daily rations (Załachowski, 1985) showed no such differences to have existed, one has to assume that the cause of the poor fit is of a different nature. The daily ration studies mentioned demonstrated considerable differences between feeding intensities of cod in various age groups. The differences are manifest as a tendency of daily coefficients to decrease with age, the rate of decrease being at its highest in the youngest age groups. This means that the younger cod eat more, relative to their weight, than the older fish. Consequently, the amount of food consumed by the whole population depends not only on its biomass, but also on its age composition.

The above reasoning leads to a conclusion that the consumption-biomass relationship should be analysed for each age group seperately, a good fit being expected. Such an analysis has been made, its results presented in Fig. 3 and Table 1 being as expected. In all but two age groups correlation coefficients for a linear relationship exceed 0.96 . The lowest coefficient (0.86) was obtained in age group VI where - as seen in Fig. 3 -- cod of almost identical biomasses in 1978 and 1979 consumed widely different amounts of food. The difference was caused by an accidental (not repeated anywhere on such a scale) difference between mean daily coefficients in the two years compared. A slightly lower (0.93) correlation coefficient in age group I might have been caused by the fact that cod biomasses were similar in four out of six years compared.

Fig. 3 explains the relatively large scatter of points ing Fig. 2. The total consumption in 1977 and 1980 was higher than the mean. The causes, however, differ in each year. In 1980, it was caused by a higher feeding intensity, which is indicated by points in Fig. 3 located - in age groups I-V - above the regression line. On the other hand, the total consumption in 1977 was affected by an exceptionally large biomass of age group I, the cod of this group eating, on the average, at least twice as much as do the older cod, relative to their weight. Thie consumption to biomass ratio is evidenced by the direction

Table 1

Parameters of the equation $y=a x+b(y=$ annual consumption in thou. $t$; $\mathrm{x}=$ cod biomass in thou. $\mathrm{t} ; \mathrm{r}=$ correlation coefficient) and consumption to biomass ratio $(y: x)$ in various cod age groups

\begin{tabular}{|r|rrr|l|}
\hline Age & \multicolumn{1}{|c}{$\mathrm{a}$} & $\mathrm{b}$ & $\mathrm{r}$ & $\mathrm{y}: \mathrm{x}$ \\
\hline I & 13.968 & -238.40 & 0.9271 & $9.6 \pm 0.69$ \\
II & 5.043 & -27.19 & 0.9755 & $4.8 \pm 0.19$ \\
III & 4.283 & 43.54 & 0.9634 & $4.6 \pm 0.18$ \\
IV & 5.548 & -159.60 & 0.9865 & $4.2 \pm 0.20$ \\
V & 5.287 & -83.31 & 0.9749 & $4.2 \pm 0.20$ \\
VI & 4.096 & 7.00 & 0.8575 & $4.3 \pm 0.38$ \\
VII & 4.034 & -3.93 & 0.9831 & $3.8 \pm 0.11$ \\
VIII & 3.787 & -0.88 & 0.9861 & $3.7 \pm 0.09$ \\
IX & 4.002 & -1.12 & 0.9896 & $3.7 \pm 0.09$ \\
X & 4.040 & -0.52 & 0.9966 & $3.7 \pm 0.09$ \\
\hline
\end{tabular}




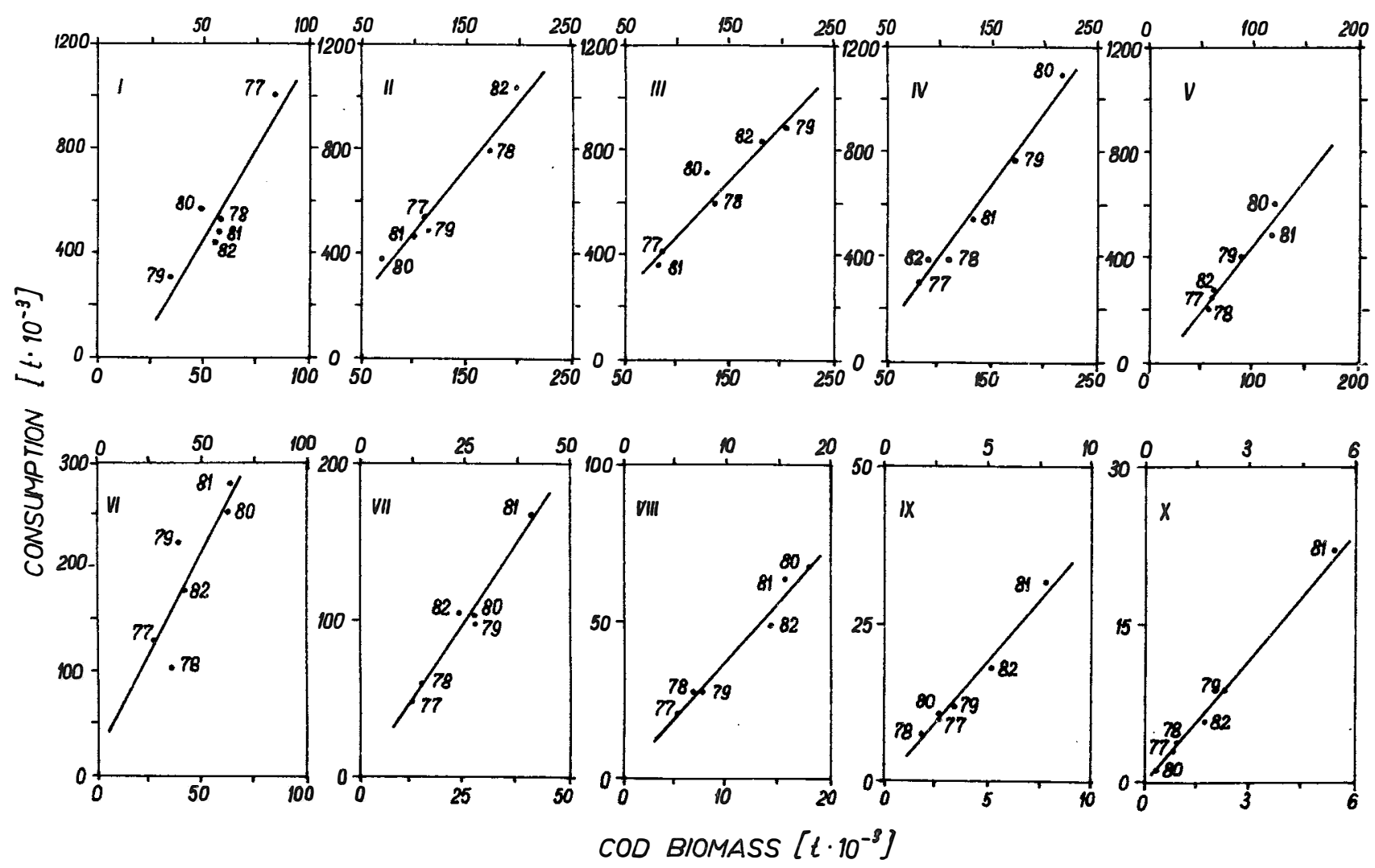

Fig. 3. Relationship between annual consumption and cod biomass in age groups $I$ to $X(t=$ metric tonnes) 


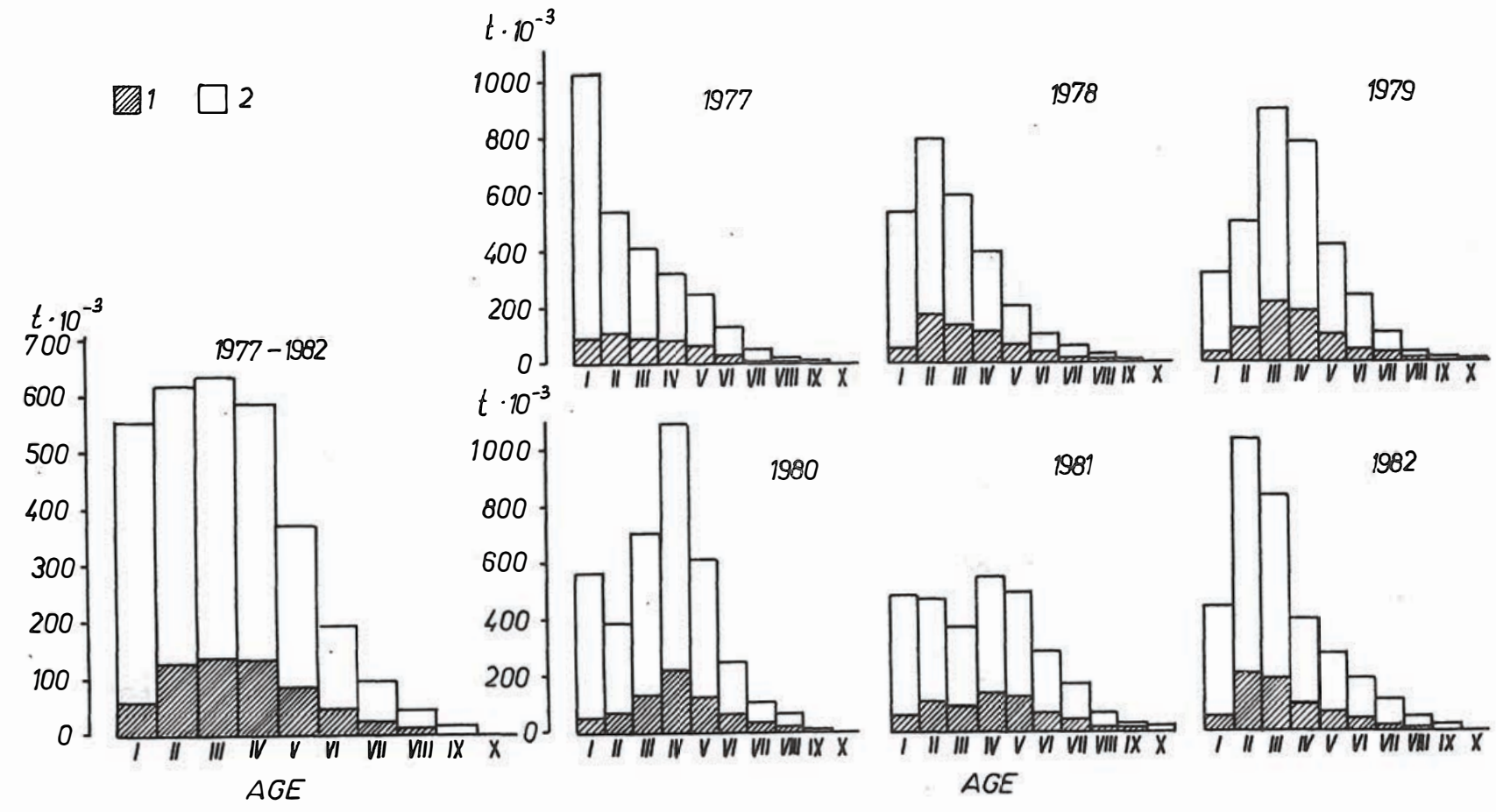

Fig. 4. Distribution of biomass (1) and annual consumption (2) in cod age groups $(t=$ metric tonnes) 
coefficient, a, given in Table 1 . In view of the widely fluctuating values of the free term, $b$, particularly in younger years, the trend in changes of the direction coefficient was somewhat deformed. For this reason, Table 1 contains also empirical means of the consumption to biomass ratio, the means reflecting clearly the age-dependent decreasing trend in the relative amount of food consumed.

Fig. 4 shows the distribution of food mass between various age groups in each year and the mean distribution over the 6 years studied. The graph shows the distribution to be dependent on fish biomass distribution, the latter changing with changes in the population's age structure. At first, the biomass is seen to shift toward older age groups until, in 1980, age group IV dominated, groups IV and V being dominant in 1981. A rejuvenation occurred in 1982; in consequence, age groups II and III dominated the total biomass again.

\section{Food composition}

The composition of food consumed in various years is presented in Tables $2-4$ and in Figs. 5 - 9. Table 2 lists all the items found and their estimated amounts consumed (in thou. t). Figs. 5-9 show what part of the biomass of each item was consumed by the cod belonging to the ten consecutive age groups. The items are grouped in assemblages based on varying criteria; each figure - apart from showing the situation in each calendar year - illustrates mean values for the 6-yr period of study. Tables 3 and 4 provide per cent contribution of items constituting the assemblages mentioned in the food biomass consumed by all the cod.

Trends in changes of the role played by various items in the food of older and older cod correspond to those shown in studies on partial daily coefficients (Załachowski, 1985). The other factor considered here, that is cod biomass in various age groups, allows to specify more precisely each item's role in the food weight taken up by the whole population. An example can be found in the fish to invertebrates ratio. Daily coefficients indicated a constant increase in the proportion of fish in food, up to the highest level in the oldest age groups. Fig. 5 confirms this trend; at the same time a rapid decrease in biomass of cod of those age groups where fish dominate in food is documented as well. As a result, if 6-yr means are considered, invertebrates make up $60 \%$ of the total food weight (Table 4) in spite of their dominating over fish in the first three age groups only. Over the 6 years of study, invertebrates dominated 3 times, the ratio between the two food item groups being about equal 3 times. The fish did not prevail even in 1977 when the indices of their consumption were very high from age group II onward. In that year, an exceptionally high biomass of age group I cod feeding almost exclusively on invertebrates generally balanced the proportions of the two groups of items. Although the population's age affects the fish to invertebrate ratio, age effects are not decisive, as evidences by the situation observed in 1980 when the "old" (age group IV-dominated biomass) cod population reached the highest index of consumption of invertebrates over the 6 years of study. 

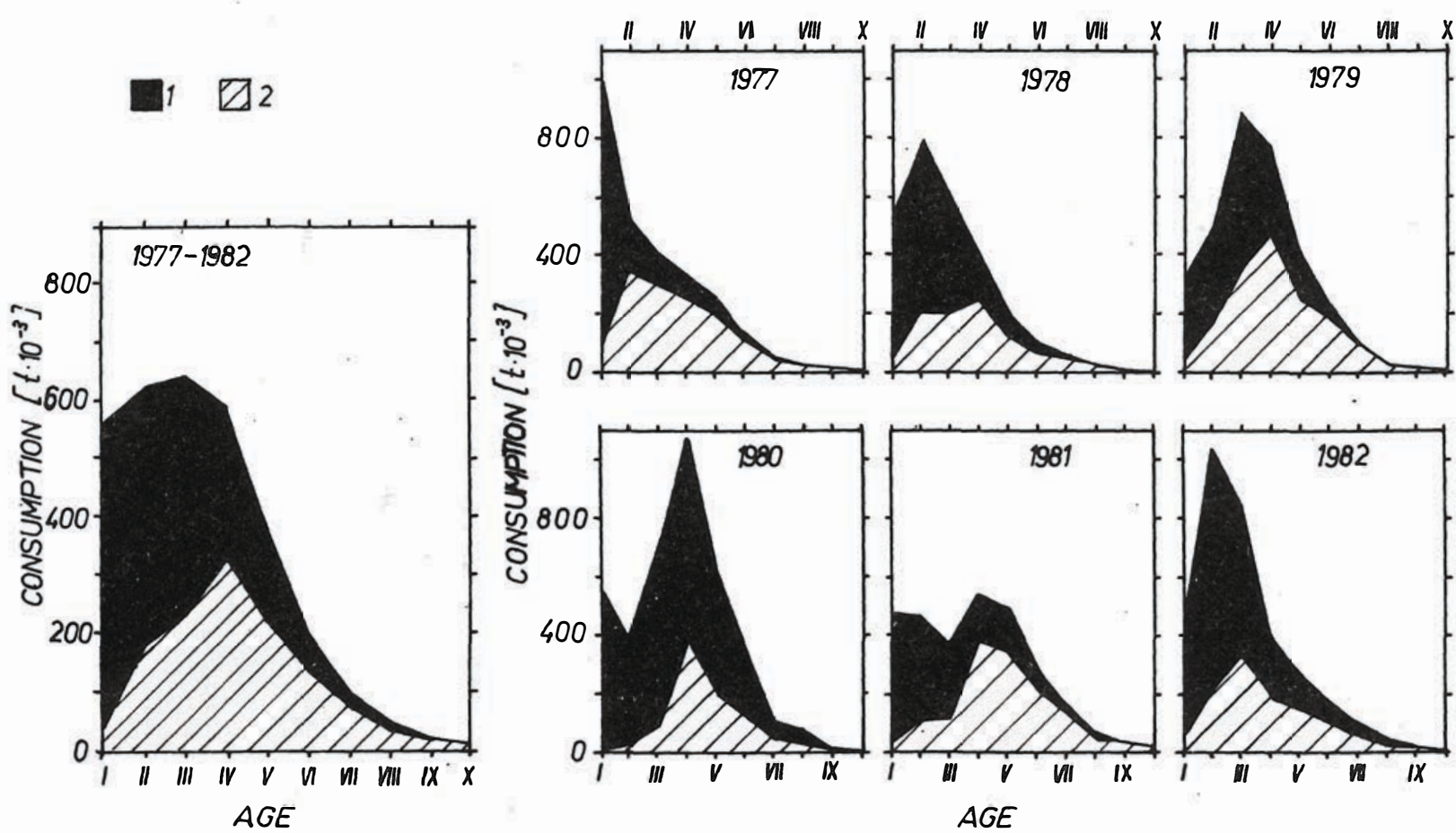

Fig. 5. Annual consumption (metric tonnes) of invertebrates (1) and fish (2) by cod of various age groups 
Table 2

Food biomass (thou. t) consumed by the whole cod population within 1977-1982

\begin{tabular}{|c|c|c|c|c|c|c|}
\hline \multirow{2}{*}{ Food item } & \multicolumn{6}{|c|}{ Year } \\
\hline & 1977 & 1978 & 1979 & 1980 & 1981 & 1982 \\
\hline \multicolumn{7}{|l|}{ Annelida: } \\
\hline Halicryptus spinulosus & - & 0.79 & - & 0.10 & - & 1.28 \\
\hline Priapulus caudatus & 2.68 & 7.88 & 1.72 & 2.42 & 2.57 & 3.44 \\
\hline Nereis diversicolor & 11.40 & 35.09 & 80.37 & 36.40 & 17.35 & 89.88 \\
\hline Antinoella sarsi & 517.16 & 235.42 & 189.54 & 1448.17 & 405.67 & 327.48 \\
\hline Scoloplos armiger & - & 0.21 & - & - & 0.09 & - \\
\hline Nemertini & 1.24 & - & - & - & - & - \\
\hline \multicolumn{7}{|l|}{ Crustacea: } \\
\hline Entomostraca & 19.62 & 0.17 & 1.25 & 1.82 & - & - \\
\hline Mysis mixta & 161.59 & 191.84 & 243.63 & 228.13 & 391.09 & 461.84 \\
\hline Neomysis vulgaris & 77.40 & 19.44 & 25.66 & 3.45 & 0.23 & 7.96 \\
\hline Pontoporeia affinis & 124.75 & 36.42 . & 9.74 & 100.98 & 27.34 & 136.56 \\
\hline Pontoporeia femorata & 47.37 & 13.23 & 218.69 & 164.79 & 3.38 & 10.94 \\
\hline Caliopius rathkei & 0.00 & - & - & - & - & - \\
\hline Gammarus sp. & 43.34 & 88.14 & 54.84 & 51.86 & 16.20 & 104.73 \\
\hline Corophium sp. & 0.53 & 18.51 & 12.16 & 8.85 & $i .07$ & 17.30 \\
\hline Hyperia galba & 1.88 & 3.40 & 0.15 & 0.86 & 0.08 & 0.24 \\
\hline Diastylis rathkei & 37.58 & 17.79 & 39.63 & 1.43 & 12.29 & 15.70 \\
\hline Jaera sp. & 0.03 & 0.00 & - & - & - & - \\
\hline Idotea $s p$ & 0.06 & - & -- & - & 0.21 & - \\
\hline Mesidotea entomon & 329.61 & 993.02 & 618.58 & 797.28 & 536.21 & 858.32 \\
\hline Crangon crangon & 20.07 & 47.23 & 102.64 & 26.58 & 48.09 & 113.57 \\
\hline Bivalvia: & 0.07 & 0.21 & 0.66 & 0.71 & 3.49 & 0.55 \\
\hline \multicolumn{7}{|l|}{ Pisces: } \\
\hline Gobiidae & 55.91 & 44.79 & 132.60 & 5.04 & 59.92 & 120.63 \\
\hline Sprattus sprattus & 408.04 & 126.89 & 71.18 & 203.85 & 181.80 & $368.94 *$ \\
\hline Clupea harengus & 412.34 & 183.96 & 558.53 & 399.54 & 561.82 & $139.46 *$ \\
\hline Clupeidae indetermin. & 330.53 & 309.87 & 297.28 & 180.95 & 343.86 & 284.66 \\
\hline Osmerus eperlanus & - & 2.35 & 9.19 & - & .- & 0.40 \\
\hline Gasterosteus aculeatus & 0.09 & 18.61 & 11.47 & 3.72 & 0.50 & 0.55 \\
\hline Syngnathus typhle & 0.03 & 0.37 & 0.36 & 0.03 & - & .... \\
\hline Belone belone & 2.92 & 0.45 & - & - & 0.13 & - \\
\hline Ammodytidae & 2.96 & 9.94 & 28.97 & 10.80 & 14.65 & 22.28 \\
\hline Rutilus rutilus & - & 7.52 & - & - & - & - \\
\hline Pholis gunnelus & - & - & - & 6.80 & - & 0.10 \\
\hline Lumpenus lampretaeformis & - & - & 6.64 & - & - & - \\
\hline Zoarces viviparus & - & - & 12.87 & - & - & - \\
\hline Agonus cataphractus & - & - & - & - & - & 0.37 \\
\hline Platichthys flesus & 9.25 & 0.09 & - & 2.75 & 3.54 & 5.38 \\
\hline Enchelyopus cimbrius & 2.58 & 29.09 & 91.90 & 7.89 & 184.04 & 79.72 \\
\hline Gadus morhua & 67.53 & 216.81 & 246.66 & 26.68 & 64.31 & 16.12 \\
\hline indeterminata & 59.42 & 41.56 & 137.52 & 77.20 & 46.17 & 69.76 \\
\hline ova & - & - & 5.69 & - & - & - \\
\hline Total & 2747,98 & 2701,09 & 3210.12 & 3799.08 & 2926.10 & 3318.16 \\
\hline \multicolumn{7}{|c|}{ * after dividing unidentified clupcids } \\
\hline Sprattus sprattus & 594.95 & 256.11 & 128.69 & 279.80 & 474.65 & 605.72 \\
\hline Clupea harengus & 555.96 & 364.61 & 798.30 & 504.54 & 612.83 & 2.37 .34 \\
\hline Cod biomass & 477.96 & 599.62 & 697.58 & 701.93 & $629.5 i)$ & 675.14 \\
\hline
\end{tabular}


Table 3

Contribution (\%) of various items to food biomass (or a part of it) consumed by the cod population in various years

\begin{tabular}{|c|c|c|c|c|c|c|c|c|}
\hline \multirow{2}{*}{ Food item } & \multirow{2}{*}{ Per cent of } & \multicolumn{7}{|c|}{ Year } \\
\hline & & 1977 & 1978 & 1979 & 1980 & 1981 & 1982 & $1977-1982$ \\
\hline Pisces & $\begin{array}{l}\text { total food } \\
\text { biomass }\end{array}$ & 49.2 & 36.7 & 50.2 & 24.4 & 49.9 & 35.3 & $40.1^{1}$ \\
\hline $\begin{array}{l}\text { Gobiidae dae } \\
\text { Clupeidae } \\
\text { Enchelyopus cimbrius } \\
\text { Gadus morhua } \\
\text { varia } \\
\text { indeterminata }\end{array}$ & $\begin{array}{c}\text { Pisces } \\
\quad, \\
\quad \\
\quad \\
\quad \\
\quad\end{array}$ & $\begin{array}{r}4.1 \\
85.2 \\
0.2 \\
5.0 \\
1.1 \\
4.4\end{array}$ & $\begin{array}{r}4.5 \\
62.6 \\
2.9 \\
21.8 \\
4.0 \\
4.2\end{array}$ & $\begin{array}{r}8.2 \\
57.5 \\
5.7 \\
5.7 \\
15.3 \\
4.8 \\
8.5\end{array}$ & $\begin{array}{r}0.5 \\
84.8 \\
0.8 \\
2.9 \\
2.7 \\
8.3\end{array}$ & $\begin{array}{r}4.1 \\
74.4 \\
12.6 \\
4.4 \\
1.3 \\
3.2\end{array}$ & $\begin{array}{r}10.3 \\
72.2 \\
6.8 \\
2.2 \\
2.5 \\
6.0\end{array}$ & $\begin{array}{r}5.6 \\
72.1 \\
5.3 \\
8.6 \\
2.7 \\
5.7\end{array}$ \\
\hline $\begin{array}{l}\text { Sprattus sprattus } \\
\text { Clupea harengus } \\
\text { Clupeidae indeterm. }\end{array}$ & $\begin{array}{c}\text { Clupeidae } \\
\quad " \\
"\end{array}$ & $\begin{array}{l}35.5 \\
35.8 \\
28.7\end{array}$ & $\begin{array}{l}20.5 \\
29.6 \\
49.9\end{array}$ & $\begin{array}{r}7.7 \\
60.2 \\
32.1\end{array}$ & $\begin{array}{l}26.0 \\
50.9 \\
23.1\end{array}$ & $\begin{array}{l}16.7 \\
51.7 \\
31.6\end{array}$ & $\begin{array}{l}43.8 \\
22.5 \\
33.7\end{array}$ & $\begin{array}{l}25.1 \\
42.6 \\
32.3\end{array}$ \\
\hline $\begin{array}{l}\text { Sprattus sprattus }{ }^{2} \\
\text { Clupea harengus }\end{array}$ & $\begin{array}{c}\text { Clupeidae } \\
,,\end{array}$ & $\begin{array}{l}51.7 \\
48.3\end{array}$ & $\begin{array}{l}41.3 \\
58.7\end{array}$ & $\begin{array}{l}13.9 \\
86.1\end{array}$ & $\begin{array}{l}35.7 \\
64.3\end{array}$ & $\begin{array}{l}43.6 \\
56.4\end{array}$ & $\begin{array}{l}71.8 \\
28.2\end{array}$ & $\begin{array}{l}43.2 \\
56.8\end{array}$ \\
\hline
\end{tabular}

1 values characterising the 6-yr period are not exactly equal to arithmetic means derived from values for each year

2 after dividing unidentified clupeids 
Contribution ( $\%$ ) of various items to food biomass (or a part of it) consumed by the cod population in different years

\begin{tabular}{|c|c|c|c|c|c|c|c|c|}
\hline \multirow{2}{*}{ lood item } & \multirow{2}{*}{ Per cent of } & \multicolumn{7}{|c|}{ Year } \\
\hline & & 1977 & 1978 & 1979 & 1980 & 1981 & 1982 & $1977-1982$ \\
\hline Invertebrata & $\begin{array}{l}\text { total food } \\
\text { biomas }\end{array}$ & 50.8 & 63.3 & 49.8 & 75.6 & 50.1 & 64.7 & $59.9^{1}$ \\
\hline $\begin{array}{l}\text { Polychacta } \\
\text { small Crustacea } \\
\text { large Crustacea } \\
\text { varia }\end{array}$ & $\begin{array}{c}\text { Invertebrata } \\
\text {, } \\
\text {, }\end{array}$ & $\begin{array}{r}37.8 \\
36.8 \\
25.1 \\
0.3\end{array}$ & $\begin{array}{r}15.8 \\
22.8 \\
60.9 \\
0.5\end{array}$ & $\begin{array}{r}16.9 \\
37.9 \\
45.1 \\
0.1\end{array}$ & $\begin{array}{r}51.6 \\
19.6 \\
28.7 \\
0.1\end{array}$ & $\begin{array}{r}28.9 \\
30.8 \\
39.9 \\
0.4\end{array}$ & $\begin{array}{r}19.5 \\
35.1 \\
45.2 \\
0.2\end{array}$ & $\begin{array}{r}30.5 \\
29.2 \\
40.0 \\
0.3\end{array}$ \\
\hline $\begin{array}{l}\text { Antinoella sarsi } \\
\text { Nereis diversicolor } \\
\text { varia }\end{array}$ & $\begin{array}{c}\text { Polychaeta } \\
. . \\
. .\end{array}$ & $\begin{array}{r}97.1 \\
2.1 \\
0.8\end{array}$ & $\begin{array}{r}84.3 \\
12.5 \\
3.2\end{array}$ & $\begin{array}{r}69.8 \\
29.6 \\
0.6\end{array}$ & $\begin{array}{r}97.4 \\
2.4 \\
0.2\end{array}$ & $\begin{array}{r}95.3 \\
4.1 \\
0.6\end{array}$ & $\begin{array}{r}77.6 \\
21.3 \\
1.1\end{array}$ & $\begin{array}{r}90.7 \\
8.6 \\
0.7\end{array}$ \\
\hline $\begin{array}{l}\text { Mesidotea entomon } \\
\text { Crangon crangon }\end{array}$ & $\begin{array}{l}\text { large } \\
\text { Crustacea } \\
\qquad,\end{array}$ & $\begin{array}{r}94.3 \\
5.7\end{array}$ & $\begin{array}{r}95.5 \\
.4 .5\end{array}$ & $\begin{array}{l}85.8 \\
14.2\end{array}$ & $\begin{array}{r}96.8 \\
\cdot \quad 3.2\end{array}$ & $\begin{array}{r}91.8 \\
8.2\end{array}$ & $\begin{array}{l}88.3 \\
11.7\end{array}$ & $\begin{array}{r}92.0 \\
8.0\end{array}$ \\
\hline $\begin{array}{l}\text { Mysis mixta } \\
\text { Amphipoda } \\
\text { varia }\end{array}$ & $\begin{array}{c}\text { small } \\
\text { Crustacea } \\
\qquad, \\
, "\end{array}$ & $\begin{array}{l}31.4 \\
42.4 \\
26.2\end{array}$ & $\begin{array}{r}49.3 \\
41.1 \\
9.6\end{array}$ & $\begin{array}{l}40.2 \\
48.8 \\
11.0\end{array}$ & $\begin{array}{r}40.6 \\
58.2 \\
1.2\end{array}$ & $\begin{array}{r}86.5 \\
10.6 \\
2.9\end{array}$ & $\begin{array}{r}61.1 \\
35.7 \\
3.2\end{array}$ & $\begin{array}{r}51.2 \\
40.2 \\
8.6\end{array}$ \\
\hline $\begin{array}{l}\text { Pontoporeia affinis } \\
\text { Pontoporeia femorata } \\
\text { Gammarus sp. } \\
\text { varid }\end{array}$ & $\begin{array}{c}\text { Amphipoda } \\
\text {," } \\
\text {, }\end{array}$ & $\begin{array}{r}57.3 \\
21.7 \\
19.9 \\
1.1\end{array}$ & $\begin{array}{r}22.8 \\
8.3 \\
55.2 \\
13.7\end{array}$ & $\begin{array}{r}3.3 \\
74.0 \\
18.5 \\
4.2\end{array}$ & $\begin{array}{r}30.9 \\
50.3 \\
15.8 \\
3.0\end{array}$ & $\begin{array}{r}56.9 \\
7.0 \\
33.7 \\
2.4\end{array}$ & $\begin{array}{r}50.6 \\
4.1 \\
38.8 \\
6.5\end{array}$ & $\begin{array}{r}33.1 \\
34.8 \\
27.2 \\
4.9\end{array}$ \\
\hline
\end{tabular}

${ }^{1}$ values characterising the 6-yr period are not exactly equal to arithmetic means derived from values for each year 


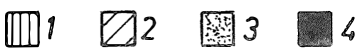
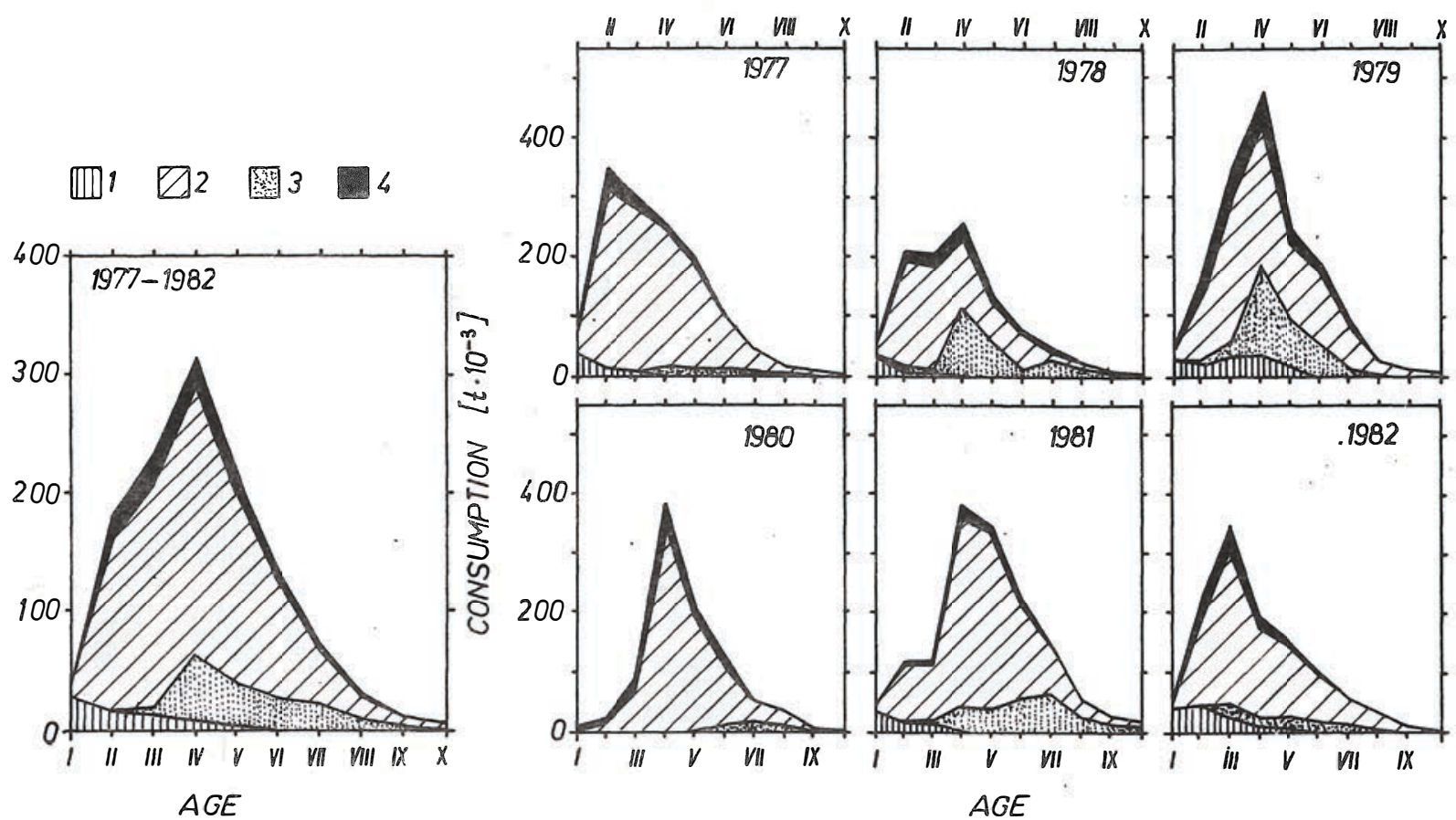

Fig. 6. Composition (metric tonnes) of fish biomass ccinsumed by cod of various age groups during a year $(1=$ Gobiidae; 2 = Clupeidae; 3 =Gadidae; 4 = other species $)$ 
The Clupeidae prevail among the fish consumed. It is only in age group I that the Gobiidae predominate over clupeids (Fig. 6). Their contribution to the total fish biomass consumed ranged from 60 to $85 \%$, depending on the year (Table 3); presumably, the contirbution is even higher assuming the fish, unidentified due to a large degree of digestion, are also clupeids. Within the clupeids, not all the fish could be identified to species. In order to estimate the biomass of sprat and herring eliminated by the cod, the unidentified clupeid biomass had to be divided between the two species. Until 1980, the division was made in each age group following the ratio between the identified sprat and herring. In the two subsequent years, another division criterion was added, namely the wieght distribution over narrow $(1 \mathrm{~cm})$ length classes of the three clupeid items. As the distribution of the unidentified clupeids turned aut to be closer to that of the sprat, most of their biomass was classified into that species (Fig. 7). If the latter method is assumed to be a more reliable one, the sprat biomass prior to 1980 was underestimated. This reservation cannot change the fact that a gradual shift in the sprat to herring ratio over 1977-1982 (the minimum sprat contribution in 1979 and a gradual increase thereafter), observed when discussing daily coefficients (Załachowski, 1985) is confirmed by converting the coefficients to the biomass eliminated (Table 3).

In the years of a lower clupeid contribution $(1978,1979)$, intensified cannibalism was recorded, the fourbearded rockling becoming the second most important food item (after the clupeids) in 1981.

Weight distributions of the major invertebrate items in various cod age groups (Fig. 8) demonstrate a rapid decrease in contributions of the Polychaeta and small Crustacea in favour of large crustaceans. Over the 6-yr period of study, large crustaceans made up, on the average, $40 \%$ of the invertebrate biomass, about $30 \%$ each being supplied by the two remaining groups. However, the proportions varied in different years (Table 4), the polychaete contribution being the most variable one. Table 4 gives also figures illustrating the composition of the three groups of invertebrate food items. Polychaetes consist in 90\%, on the average, of Antinoella sarsi, Nereis diversicolor being the second most important item exceeding $20 \%$ in some years. More than $90 \%$ of the large crustaceans biomass is made up by Mesidotea entomon, the second most important item, i.e., Crangon crangon, exceeding $10 \%$ only exceptionally. The "small crustaceans" group is made up mainly by Mysis mixta and amphipods; although M. mixta dominates in the biomass consumed over 6 years, the prevalence of amphipods was recorded in three years. Within the amphipods, three items: Pontoporeia affinis, P. femorata, and Gammarus are of a similar importance, although their contributions oscillate in different years. Fig. 9 shows in detail the weight distribution of small crustaceans among the cod age groups. 

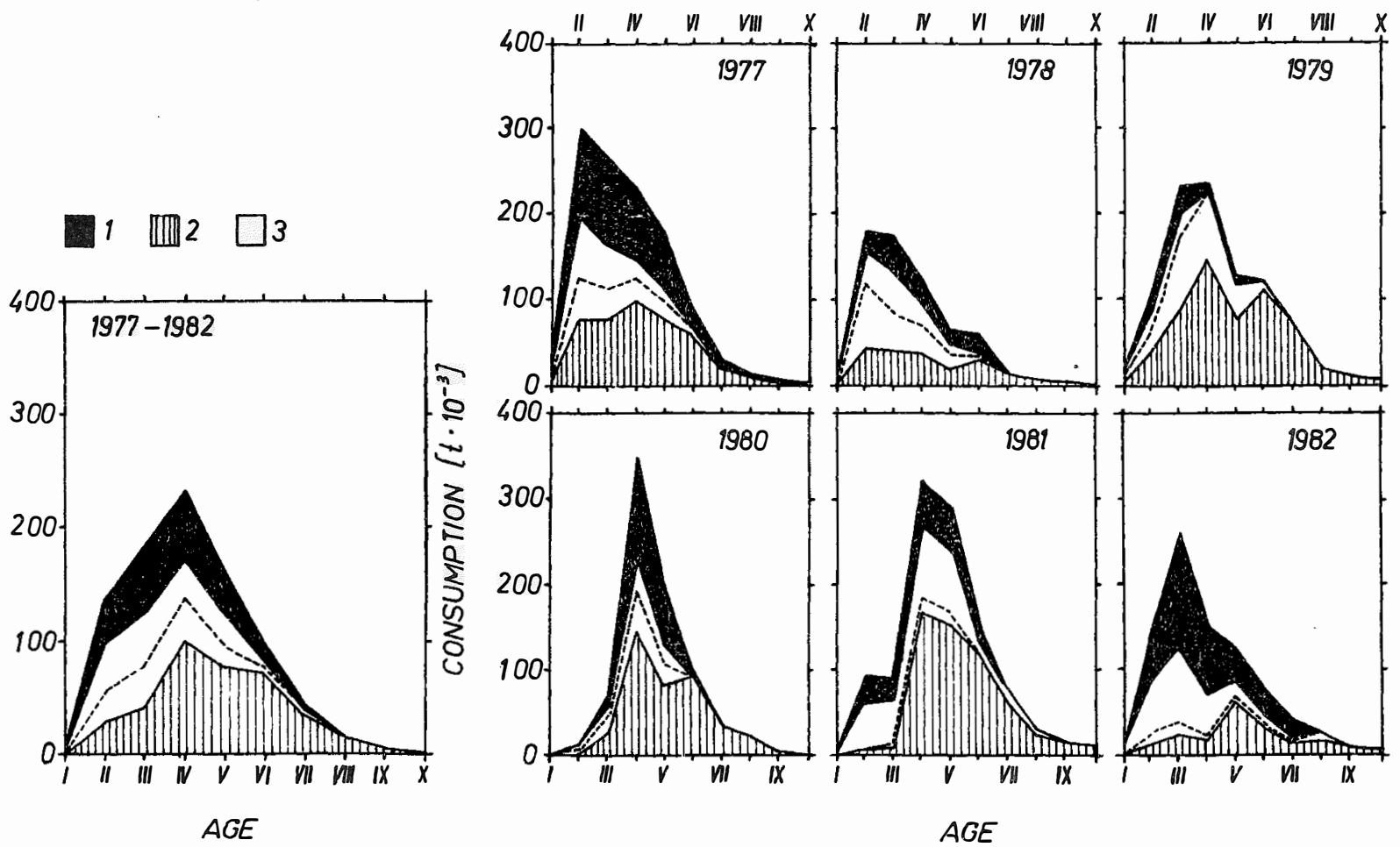

Fig. 7. Composition (metric tonnes) of the Clupeidae biomass consumed by cod of various age groups during a year (1 = Sprattus sprattus; 2 =Clupea harengus; 3 = unidentified Clupeidae $)$. Dashed line divides unidentified clupeids into sprat (above the line) and herring (below the line) 


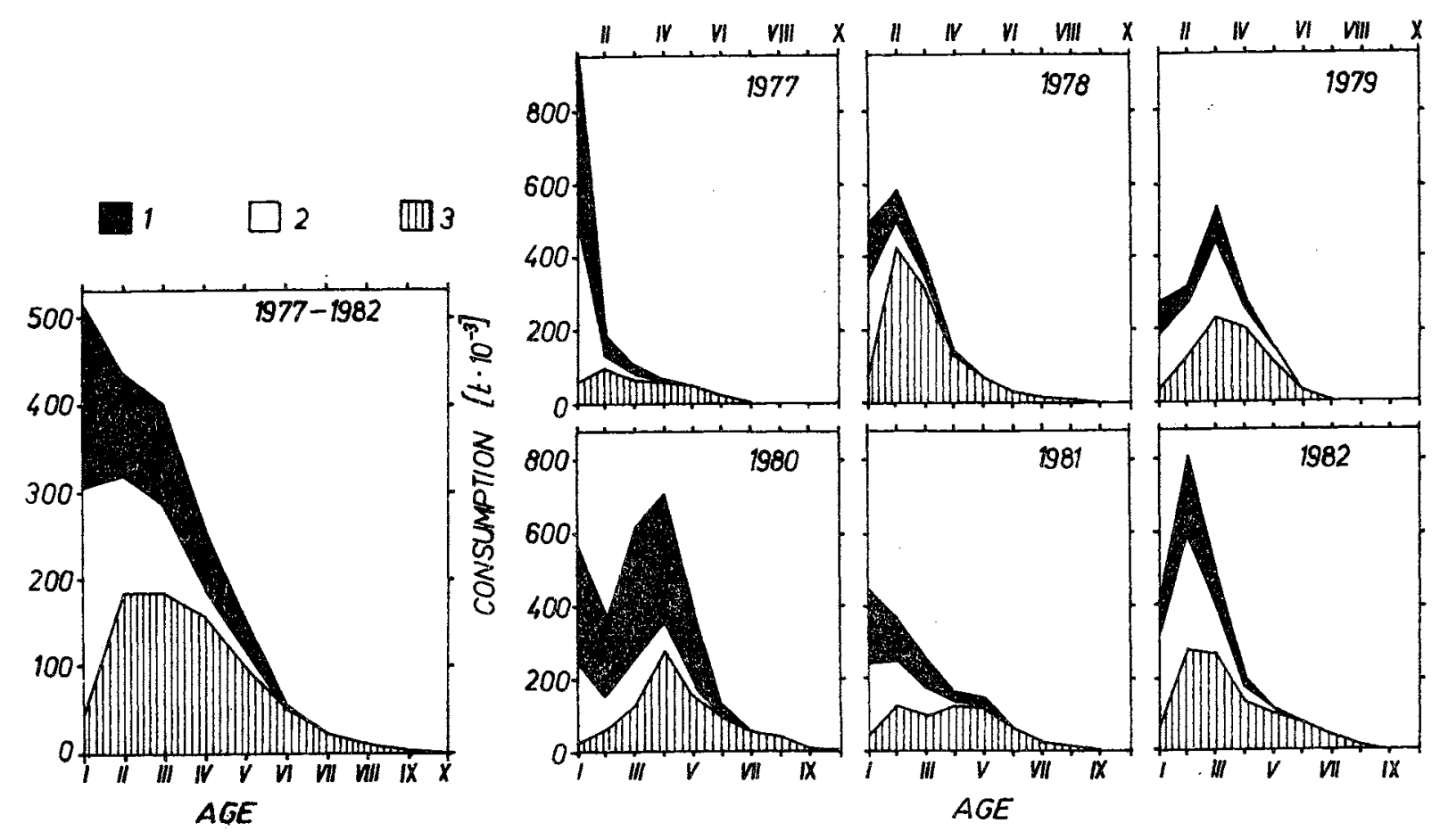

Fig. 8. Composition (metric tonnes) of invertebrate biomass consumed by cod of various age groups during a year (1 = Polychaeta; 2 = small Crustacea; 3 = large Crustacea $)$ 


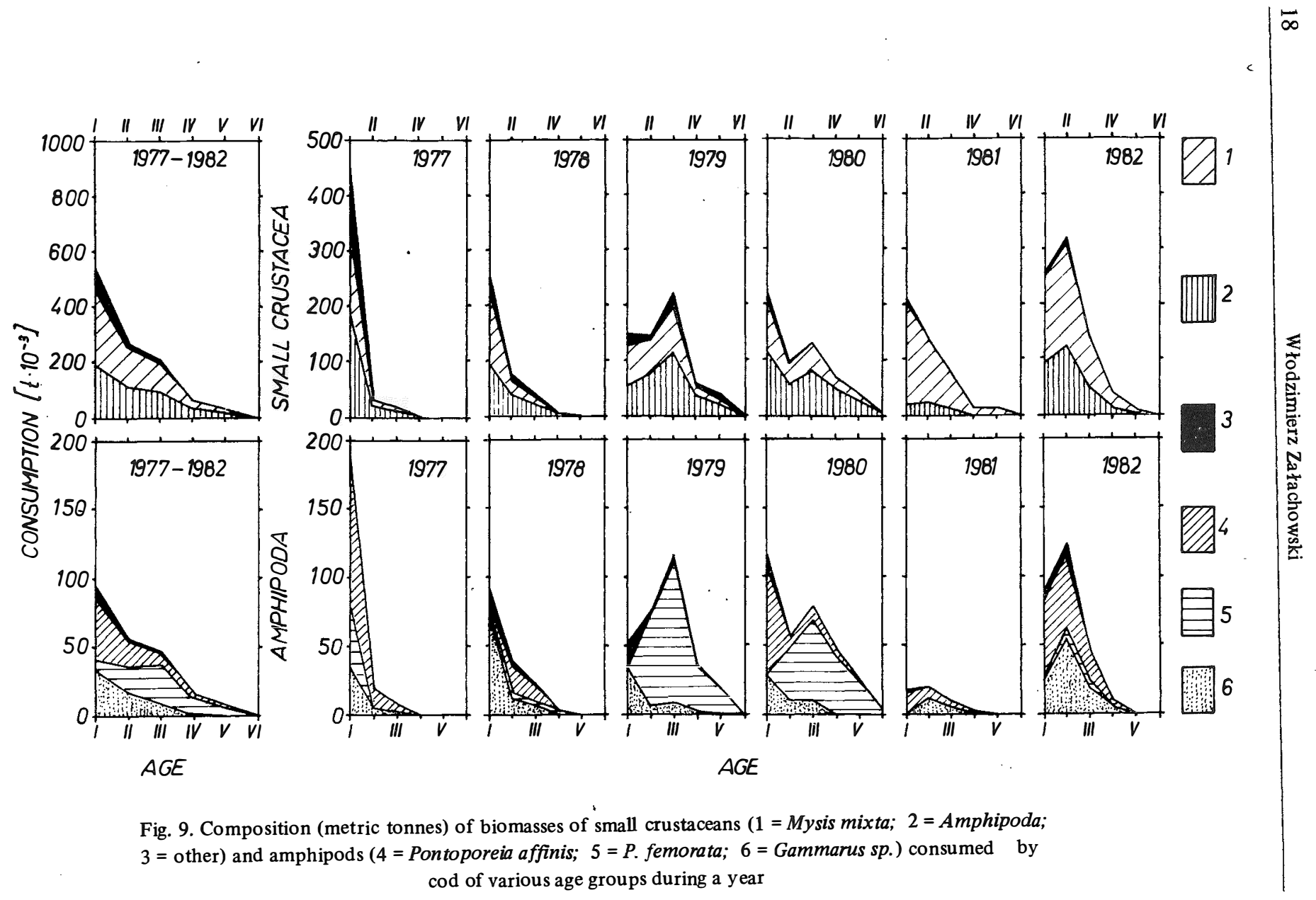




\section{DISCUSSION}

The discussion should, first of all, center around the reliability of the results presented. The figures illustrating the annual consumption are high, both those pertaining to invertebrates and to the fish. They are a combined result of the two elements of the estimation procedure used. Mean daily rations are one element and the cod biomass the other. The magnitude of mean daily ration affects the food weight to cod biomass ratio, while the cod biomass affects the absolute weight of food consumed. The ICES data on cod biomass were used and there is no reason to question their validity. Daily rations (coefficients) were calculated using a previously verified method (Załachowski, 1985) based on comparisons with experimental works of various authors, an index of food conversion to growth being one of the verification criteria. The daily ratio calculation method is assumed to yield probable results, the degree of probability depending on the way of collection (and handling) of materials to be studied (Załachowski, 1985).

The 6-yr mean food weight to cod biomass ratio was $4.95( \pm 0.2)$, the mean in age group I being twice that value. Comparative data for the Baltic Sea can be found in two sources. Uzars (1975) reports an estimation for the eastern Baltic with the ratio amounting to 13 for the population as a whole and 22 in age groups $0+$ and I. Bagge (1981) who used three methods of daily ration calculation for the western Baltic and Belt Sea found the food to biomass ratio to range from 2 to 6 , depending on the method. To use Uzar's result, the food weight estimated in the present work should be at least doubled, while to use Bagge's lower values the present result should be cut down by half. In the latter case, however, the food energy conversion to growth would proceed with an improbably high efficiency.

Consequently, there are reasons to believe that the estimated food biomass consumed can be regarded as valid. An exception is that part of the total food weight consumed by the age group I cod. It has already been shown (Załachowski, 1985) that the daily ration assessment of these cod $(0+)$ merits separate studies as a rapid growth rate of young organisms brings about equally rapid changes of feeding-related indices, which makes it difficult to find mean values for the group. On the other hand, the stock biomass estimates do not distinguish between those fractions of the biomass supplied by various developmental stages during the first year of life; different indices of food amount and composition should be applied to those stages. Therefore the weight of food consumed by the youngest cod is the most dubious item in the estimates presented. As those cod feed mainly on invertebrates, a possible error may affect the evaluation of the importance of invertebrates in food consumed by the whole population.

Insofar as the total food weight calculated here should not deviate too much from that actually consumed by the cod, the data on each item's contribution can be treated only as an attempt to gain some general overview. This is the result of the fact that food composition was determined in subareas 25 and 26 only, while the results are referred to the population inhabiting a much wider region covered by subareas 25-32. As considerable differences in food composition were recorded within the area of study, the 
differences depending on the location of feeding grounds, similar or even greater differences may be assumed to occur within the whole area inhabited by the population. Thus, to obtain more reliable results, coefficients of daily food consumption should be determined for the whole area inhabited by the stock and data on the stock distribution over the area collected, both including changes occurring throughout the year. These coefficients obtained in areas of a higher biomass should then weight more in the calculations than would those calculated for less densely inhabited areas.

\section{CONCLUSIONS}

1. The amount of food consumed by the cod population depends not only on its biomass and feeding intensity, but also on its age structure. A higher percentage of intensively feeding younger fish leads to an increased total consumption.

2. The age structure affects also composition of the food consumed by the whole population. Although invertebrates prevail usually in the food consumed by the first three age groups only, their contribution to the total food weight consumed is equal to (or even exceeds) that of fish since the oldest cod, decidedly predacious, constitutes a negligible part of the stock biomass.

3. The numerical data given in this paper will be more precise if studies on the amount and composition of food consumed cover the entire area inhabited by the cod stock. Should such studies demonstrate sizable regional differences, stock biomass distribution over the inhabited area would have to be investigated.

\section{REFERENCES}

Anonim, 1982: Report of the ad hoc Working Group on Multispecies Assessments in the Baltic". Copenhagen, 25-28 May, 1982. ICES C.M. 1982/Assess.: 15.

Anonim, 1983: Report of the Working Group on Assessment of Demersal Stocks in the Baltic. Copenhagen, 6-13 April, 1983. ICES C.M. 1983/Assess.: 15.

Bagge O., 1981: The yearly consumption of cod in the Baltic and the Kattegat as estimated from stomach content. ICES C.M. 1981/J:27, Baltic Fish C-tee.

Elwertowski J., 1982: Zasoby ryb użytkowych Bałtyku [Commercial fish resources in the Baltic]. Wyd. Morsk. Inst. Ryb.w Gdyni. Studia i materiały, s. B, No 50.

Uzars D., 1975: Peculiarities of Feeding and Quantitative Food Consumption of Eastern Baltic Cod. ICES C.M. 1975/P:4, Baltic Fish C-tee.

Załachowski W., 1985: An attempt to apply Bajkov's formula to estimation of food uptake of cod in the Southern Baltic.-Acta Ichth. et Pisc., XV, 1.

Załachowski W., 1985: A quantity and composition of food taken by cod (Gadus morhua L.) in the Southern Baltic in 1977-1982. Acta Ich th. et Pisc. XV ,2.

Translated: Dr. T. Radziejewska 
Włodzimierz Załachowski

\section{STRESZCZENIE}

Biorąc średnie współczynniki dobowe, uzyskane na podstawie badań prowadzonych w latach 1977-1982 w podobszarach statystycznych 25 i 26 (Załachowski, 1986), oraz dane pochodzące $z$ materiałów ICES na temat biomasy populacji dorszy zasiedlających rejon zawarty w podobszarach $25-32$, obliczono globalną masę pokarmu eliminowanego w ciagu roku przez całą populację, skład tej masy, oraz masę konsumowaną przez dorsze należące do poszczególnych grup wieku. Pełny wykaz wyróżnionych składników pokarmu, wraz $\mathrm{z}$ oszacowaną $\mathrm{w}$ tysiącach ton wielkością rocznej konsumpcji, podano $\mathrm{w}$ tabeli 2. Stwierdzono, że pomiędzy konsumpcją a biomasą dorszy $w$ poszczególnych grupach wieku zachodzi ściślejsza zależność prostoliniowa (rys. 3, tab.1), niż w przypadku, gdy zależność tę rozpatruje się w odniesieniu do całej populacji (rys. 2). Na ilość pokarmu pobieranego w ciągu roku, oprócz intensywności żerowania i biomasy dorszy, wpływa również struktura wieku populacji (rys. 4): większy udział intensywniej żerujących ryb z młodszych grup wieku powoduje zwiększenie globalnej konsumpcji. Struktura wieku wywiera wpływ także na skład masy pokarmu. W ogólnym bilansie wzrasta znaczenie składników zjadanych przez dorsze należące do tych grup wieku, które mają największy udział w biomasie stada (rys. 5-9, tab. 3 i 4). W całym badanym sześcioleciu bezkręgowce - zjadane głównie przez dorsze $\mathrm{z}$ trzech najmłodszych grup wieku - w ogólnej masie pokarmu przeważały nad rybami dlatego, że typowo drapieżne dorsze ze starszych grup wieku osiagały stosunkowo małą biomasę. Stwierdzono znaczne różnice ilości i składu pokarmu eliminowanego w poszczególnych latach.

ПОПЫТКА ОЦЕНКИ МАССЫ ГІИЩИ, ПОГЛОЩН̈ННОЙ В ТЕЧЕНИЕ ГОДА ПОПУЛЯЩИЕИ ТРЕСКИ GADUS MORHUA I. В БАЛТИКЕ НА ОСНОВАНИИ ИССЛЕДОВАНИИ' В IЕРИОа 1977-1.982гг.

$$
P \text { e } 3 \text { 10 M e }
$$

Принимая средние суточные козфоициенты полученные на основе исследованй, проведённых в $1977-$ -1982 гг. в статистических подрайонах 25 и 26, Залаховски, 1985), а тақе данные из материалов 
ИКЕС на тему биомассы популяции трески, заселяющей подрайоны 25-32, подсчитали общую массу пищи, поглощённой в течение года целой популяцией, состав этой массы, а также массу, съедаемую треской, принадлежапей разным возрастным группам.

Подробный состав пищи, вместе с подсчётом в тыс. тонн годовой величины съеденой пищи, показан в табл • 2.

Обнаружено, что между съеденой пищей и биомассой трески в отдельных возрастных группах наблюдается более тесная прямолинейная зависимость (Рис.3, Табл.1), чем в случае целой популяции (Рис.2). На количество пищи, принимаемой в течение года, кроме интенсивности питания и биомассы трески, влияет также структура возраста популяции (Рис.4): больщее участие более интенсивно питающихся рыб, из младпих возрастных групп, вызывает увеличение общей съеденой массы. Возрастная структура влияет также на состав массы пищи. В общем подсчёте возрастает значение состава пищи, съедаемой треской, принадлежаще тем возрастным группам, которые имеют большее значение в биомассе стада (Рис.5-9. Табл.3,4). В течение 6 лет исследований, безпозвочные - съедаемые треской, при надлежащей трём наименьщим возрастным группам, - в общей массе пици преобладали над рыбами потому, что обычно "хищная" треска из старших возрастных групп, достигало относительно небольшую биомассу. Обнаружено значительное различие в коли- 
честве и составе пищи, поглощённой в течение исследуемых лет.

Перевод: к.т.н. Лучак М.

Author's address:

Received: 15 April 1985

Doc. dr hab. Włodzimierz ZAŁACHOWSKI

Instytut Ichtiologii

ul. Kazimierza Królewicza 4

71-550 Szczecin, Polska (Poland) 